\title{
Migrant Laborers in China and Their Contributions to Rural Development
}

\author{
Charles Joseph G. De Guzman \\ Chinese Studies Program, Ateneo De Manila University, Quezon City, Philippines
}

\begin{abstract}
This paper will look at the importance that the migrant labors in China are doing today. The main question posed in this paper is "how migrant labors in China are contributing to rural development?”. Furthermore, the paper will answer the following sub-questions: (1) Is migration an important factor in the development of rural areas? (2) Can migration bridge the poverty gap between urban and rural areas? The objectives of this paper are the following: (1) to identify the migrant labors contributions in China's rural development; (2) to look into the importance of migration for the rural Chinese; and (3) to know and analyze the problems that migrant workers in China are facing in relation to their migratory work. Furthermore, this paper posits that migrant labors in China are contributing to rural development through their remittances, their investments, and the new knowledge and techniques that they acquired in the urban areas which they share in their home areas. In addition to that, this research looks at the migrant labors' remittances, their investments, and the new knowledge and techniques that they acquired in their home areas as their contributions to rural development.
\end{abstract}

Keywords: internal migration, rural development, migrant labors, "hukou” system

\section{Background of the Study}

Internal migration or the internal movement of people within their country is not a new phenomenon in China. However, with the increasing role that the migrant labors are doing which greatly affects the continuing development and transformation of China's urban economy and landscape, a closer observation and analysis are needed in order to know their roles and contributions not only for urban development but for the more important thing - the development of rural China.

Rural migrants have been an important element for the economic development of China's economic centers, the urban areas. Since its "opening-up" in 1978, which ushered for the entry of foreign companies in the country, the rural migrants were the ones who provided for "manpower" requirements of these foreign-owned companies, which mainly fuels and drives its external economy.

However, as the urban areas developed and its citizens were enjoying the fruits and benefits of these economic development and transformation, the rural areas and its people told a different story. Much focuses were given for urban development and the state is hoping that this will lead to a "trickle-down" effect. Unfortunately, the growing and increasing number of people migrating from rural areas going to urban areas is a reflection that poverty in the rural areas is prevalent and that agricultural work is not anymore the solution to augment the needs of the rural Chinese.

Charles Joseph G. De Guzman, Lecturer, Chinese Studies Program, Ateneo De Manila University. 
Moving to urban areas is now a choice for rural Chinese, especially for the younger ones to look for opportunities in non-agricultural work. However, their migration to urban areas is just temporary because their stay there depends on their employment contracts and the duration of their projects.

Their exposure to the urban areas will give them an opportunity to have additional or more resources, in terms of income and additional knowledge and skills that they can use upon return in their homes areas which will benefit not only their families but also their community. Multiplying this scenario in the whole China, it will lead to the development of the rural areas.

Thus, looking at the role that those migrant labors in China are playing today, the main question posed in this paper is "how migrant labors in China are contributing to rural development?". Furthermore, the paper will answer the following sub-questions: (1) Is migration an important factor in the development of rural areas? (2) Can migration bridge the poverty gap between urban and rural areas?

The objectives of this paper are the following: (1) To identify the migrant labors contributions in China's rural Development; (2) to look into the importance of migration for the rural Chinese; and (3) To know and analyze the problems that migrant workers in China are facing in relation to their migratory work. Furthermore, this paper posits that migrant labors in China are contributing to rural development through their remittances, their investments, and the new knowledge and techniques that they acquired in the urban areas which they share in their home areas.

The scope of the study only focused on internal migration in China. Furthermore, this paper looked at the migrant labors' remittances, their investments, and the new knowledge and techniques that they acquired in their home areas as their contributions to rural development. However, the data used in this paper in so far as migrant labors' remittances in their home provinces and their investments are concerned are based on the survey and research from second hand data, i.e., academic journals/articles, newspaper clippings, and statistical references.

The time frame for this study is from the year 1998 up to the present time. Moreover, the author used extensively second hand data from academic journals and articles, newspaper clippings related to the paper's topic, and statistical data from Chinese agencies that deal with the topic of this paper. In addition, the study also limits its focuses to some of the provinces and rural areas in China where internal migration is high and where most of the migrants came from, like Shandong, Sichuan, and Anhui.

\section{Definition of Terms}

For this paper, internal migration primarily refers to:

The voluntary movement of rural laborers, who leave their home villages for urban areas (ranging from townships, county towns and other smaller cities within or outside the province of original residence, provincial capitals and metropolitan areas), seeking non-agricultural work opportunities, usually temporary or seasonal, for at least three months a year, sometimes together with family members. (Huang \& Pieke, 2003, p. 1)

One of the major motivations for internal migration is to have remittances, which refers to money that migrant workers send back to their communities of origin (Murphy, 2007). It is an integral feature of the migration system in China. These remittances are being used by the migrant labors and their families for investments in their home areas.

Investments can be differentiated into two kinds: (1) productive investments which refer to investment in activities that increase the household's capacity to earn money (Murphy, 2007, p. 23); and (2) consumptive 
investments which refer to goods and services that immediately improve the well-being of the household members (Murphy, 2007, p. 23).

\section{Internal Migration and Urban Development in China}

The rapid surge of internal migration has been one of the most profound changes in China over the past two decades. In 1949, the founding of the People's Republic of China, rural laborers were encouraged to participate in urban construction and development.

During the 1950-1958, about 40 million workers from rural areas were recruited to urban industrial sectors. however, in the second half of the 1950s radical collectivization of agriculture "off the land" happened. To counter this flow, the government set up the "hukou" system (household registration system), adopted in China in the late 1950s, under this system, farmers could not change residence or work unit unless these changes were part of the economic plan formulated by the state (Cai, 1999).

They are classified as either "agricultural resident or non-agricultural resident", the state issues to their citizens "hukou identification" through a registration system, and the parents in turn pass their hukou to their children, which constitutes an inheritable identities and status (Li, 2007, p. 2). However, with the failures of the Great Leap Forward ${ }^{1}$ in urban construction during the late 1950s and the early 1960s, it resulted in the withdrawal of 25-30 million rural Chinese back to their villages "for the time being” (Huang \& Pieke, 2003, p. 3).

However, in 1978, through the leadership of Deng Xiaoping, China launched "gaige kaifang” (reform and opening up to the outside world), an umbrella term covering a whole range of policy areas, a remarkable point in this policy was the creation of a "socialist market economy", in which the state sector exists alongside collective, individual, private, and foreign invested enterprises (Huang \& Pieke, 2003, p. 2). Since the onset of the reforms, the various components of the non-state sector have developed quickly, especially in the coastal areas (see Figure 1).

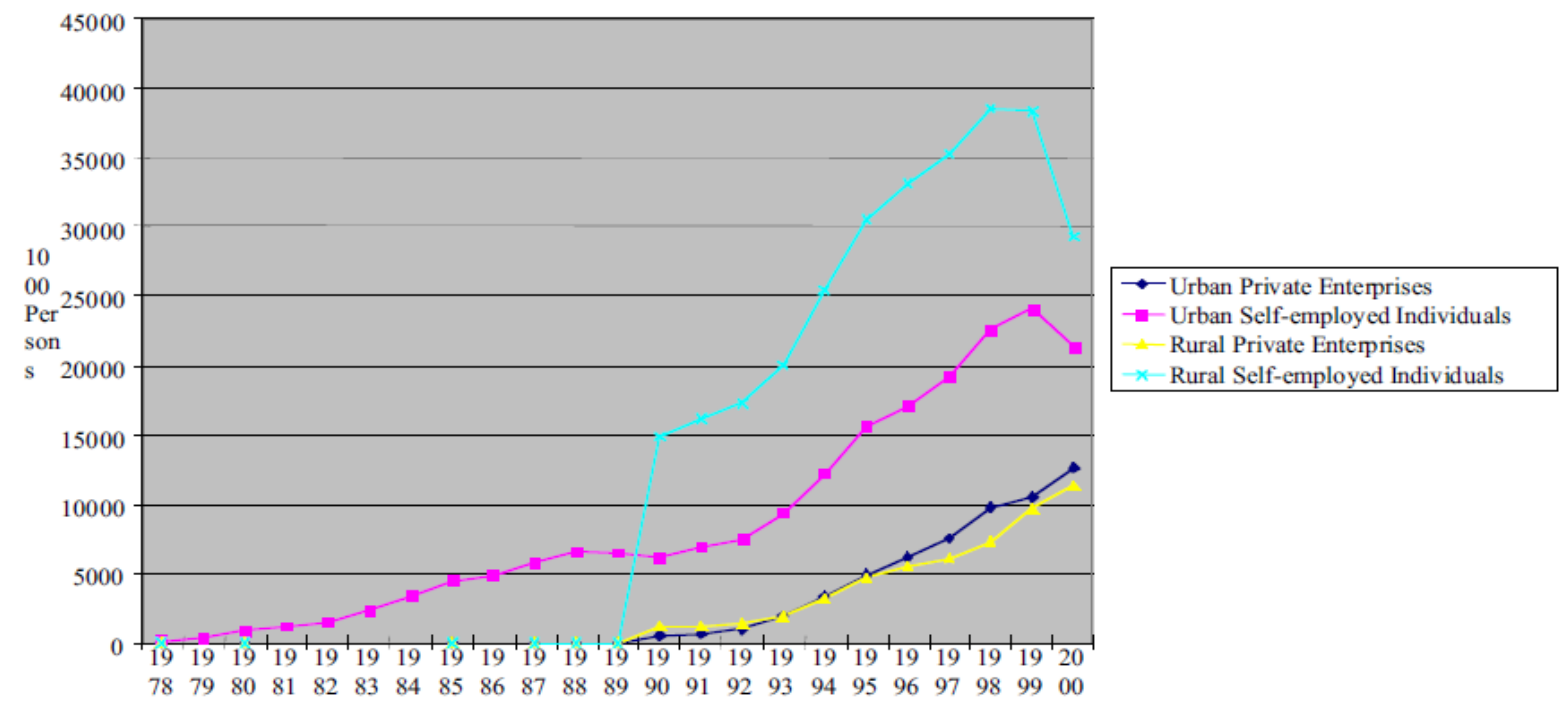

Source: National Statistical Bureau, 2001

Figure 1. Change in employment in private and individual sectors.

\footnotetext{
${ }^{1}$ It was a massive campaign that mobilized millions of people in the countryside to push agricultural production to ever greater peaks. Throughout 1958, the Great Leap Forward seemed quite successful. But sterner truths quickly emerged.
} 
Many Chinese quickly transferred from agricultural work to non-agricultural work as the opportunity in this area is increasing and promising as the country is opening, and foreign-owned companies now being allowed by the state to enter in the country have increased over the years. From the mid 1980s, the increase of income from agricultural became slower. At the same time, the governmental reform program spread to urban areas. This was especially true in the special economic zones (SEZs) and open cities in coastal areas. Urban construction projects, foreign invested, private, or collective enterprises generated a new and rapidly growing demand for cheap, temporary, and migrant labor (Huang \& Pieke, 2003, p. 4) (see Figure 2).

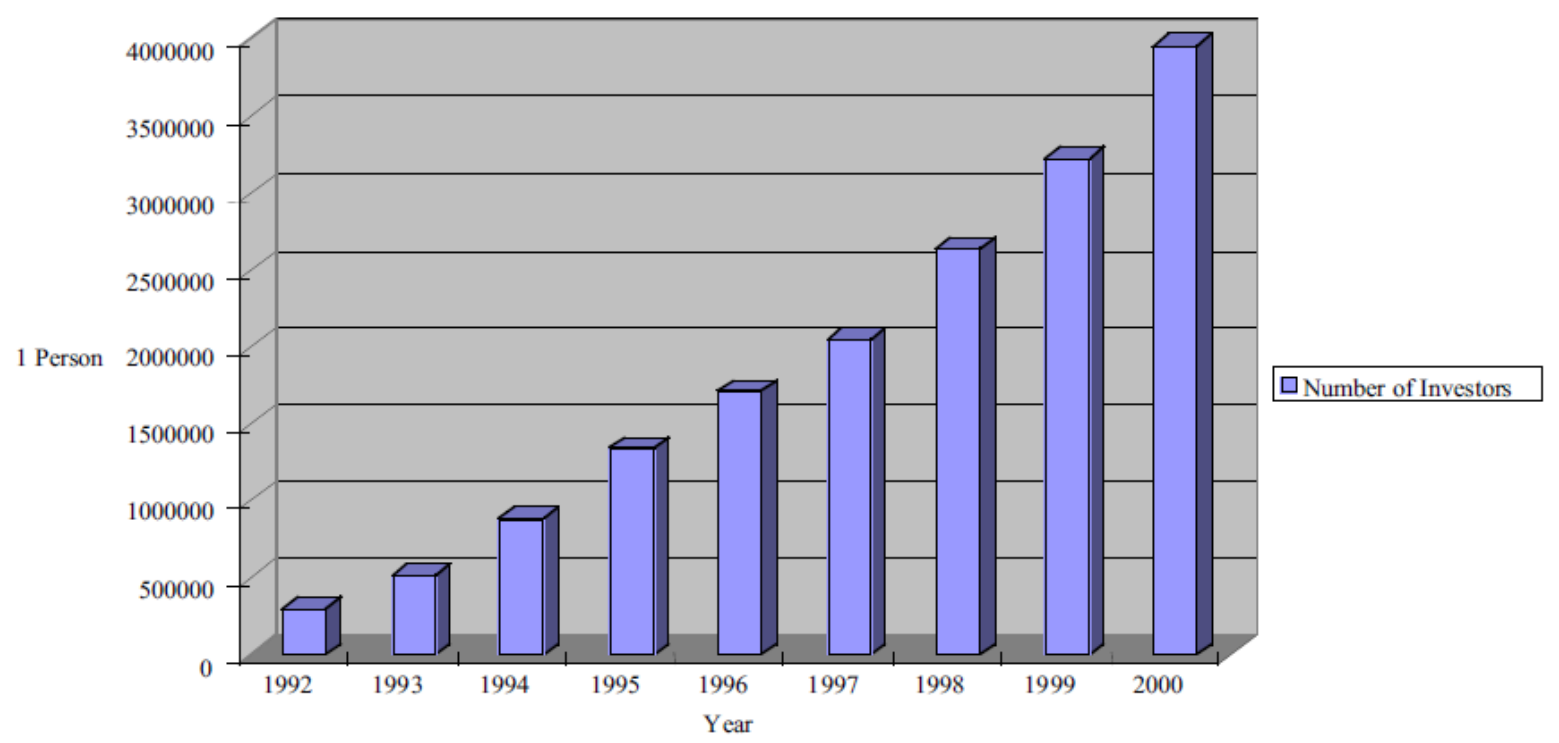

Source: National Statistical Bureau, 2001

Figure 2. Growth of number private owners and investors in China.

Rural-urban migration suddenly became a new socio-economic phenomenon in China in the late 1980s, and dealing with its consequences has become a major policy challenge for authorities both at the national level and locally in the sending and receiving areas (Huang \& Pieke, 2003, p. 4). With the relaxation of migration control, it has brought new circumstances that are more similar to those assumed by gravity models.

The state specifically introduced a series of conditions and revisions to the hukou system, so that rural Chinese are permitted to work in urban areas as temporary migrants. It is important because rural migrants have now access to the goods and services necessary for their survival in urban markets, although most rural migrants are still denied of urban hukou.

However, this new policy has unleashed massive migration. between 1990 and 2000 censuses, "inter-country migration more than doubled in size and interprovincial migration almost tripled" (Liang \& Ma, 2004; Fan, 2005) ${ }^{2}$. Such a rapid increase in mobility was largely attributed to temporary migrants (migrants

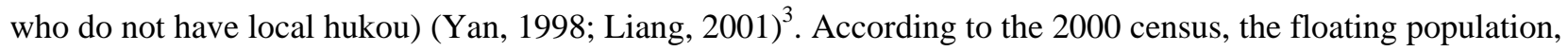
or persons whose residence is different from the hukou location, amounted to 144 million (National Bureau of Statistics, 2002) (see Figures 3, 4, \& 5).

\footnotetext{
${ }^{2}$ Cited in Ping Huang and Frank Pieke (2003). “China Migration Country Study” (p. 6).

3 Ibid., p. 6.
} 


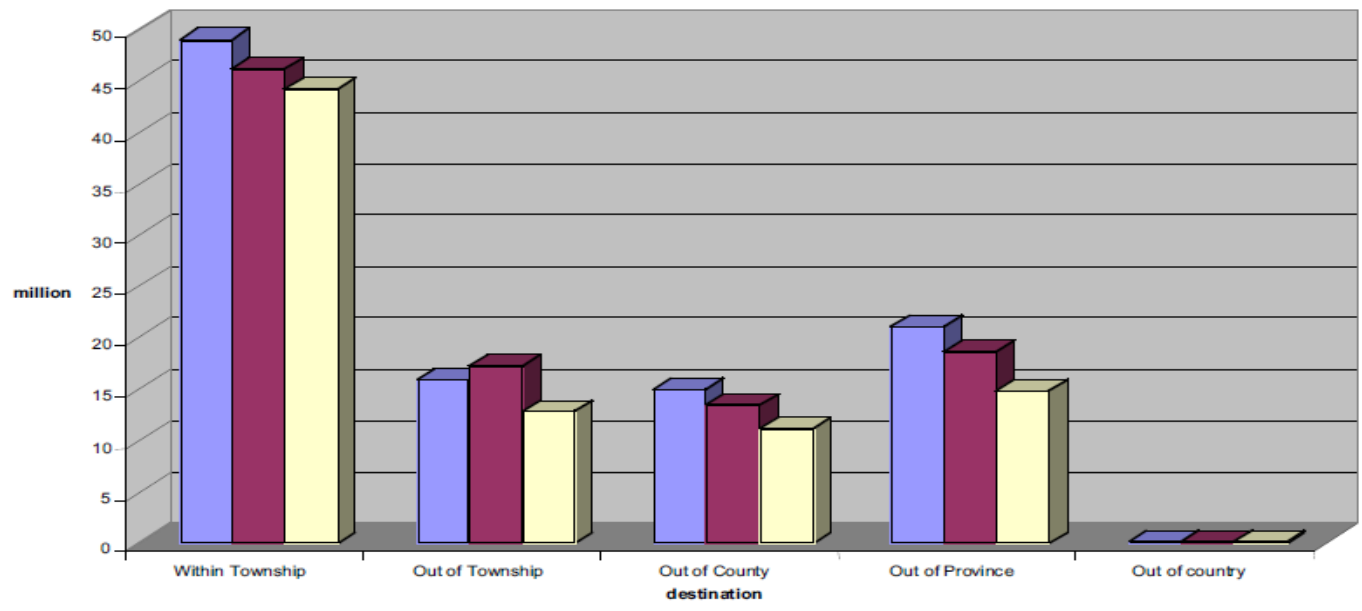

Source: Employment and Migration of Rural Labourers in China, 1999

Figure 3. Rural migrant laborers by destinations 1997-1999.

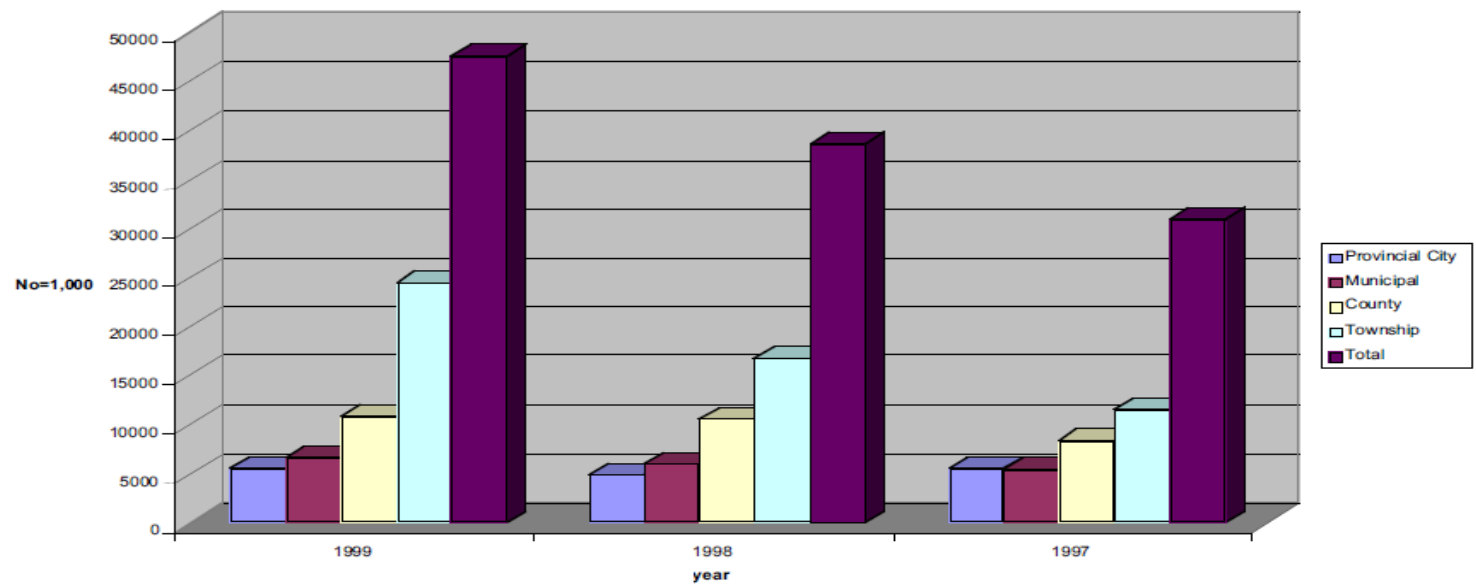

Source: Employment and Migration of Rural Labourers in China, 1999

Figure 4. Intra-provincial rural migrants 1997-1999.

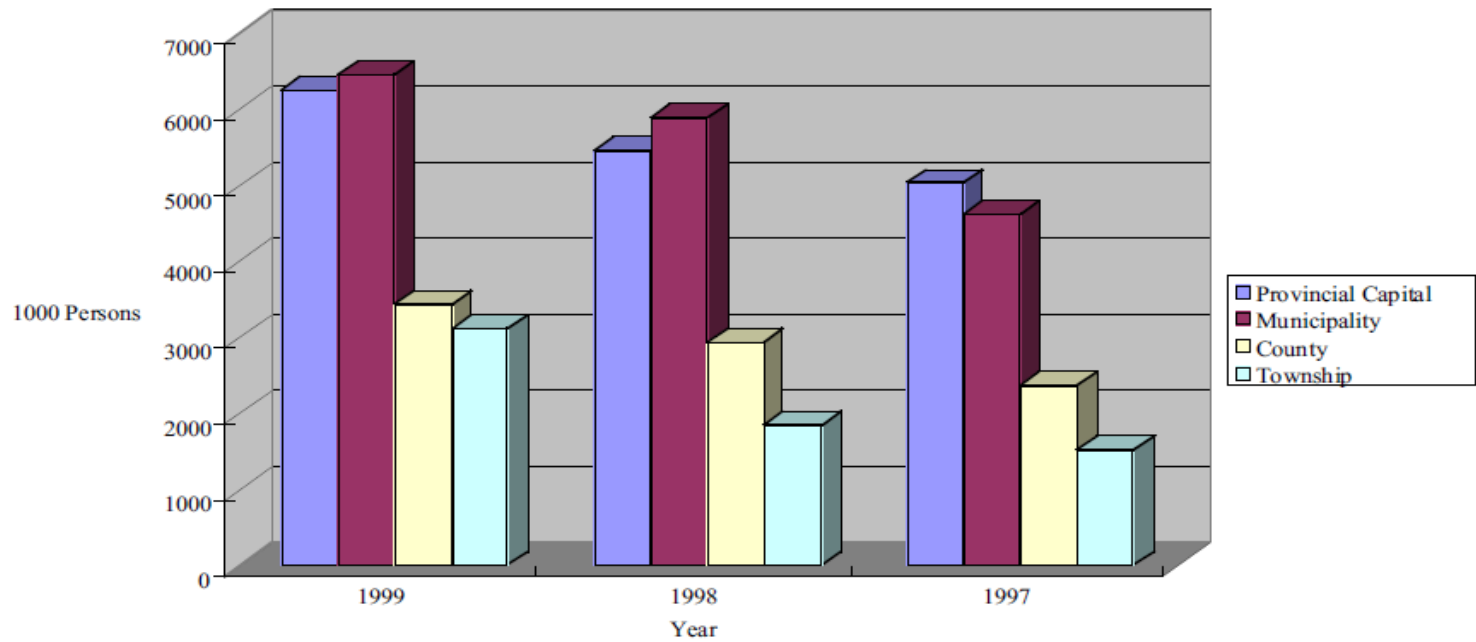

Source: Employment and Migration of Rural Labourers in China, 1999.

Figure 5. Rural labor migrants who leave their own province. 
Unfortunately, the increasing inequality between the cities and countryside and between coastal areas and the interior was due to policy choices. The reforms were based on the deliberate premise of "letting some get rich first”. Certain areas (coastal areas) and groups (educated “new” rich) were allowed to use the opportunities presented by market reforms first, in the hope and expectation that a gradual "trickle-down" effect would take place later on.

This could clearly be seen from the early strategy of southern coastal development, including the establishment of SEZs in Shenzhen, Xiamen, Zhuhai, and Shantou, followed by the opening of 14 cities, including Beijing, Shanghai, and Tianjin along the east coast, providing the world with an open door to the Chinese economy (see Figure 6).

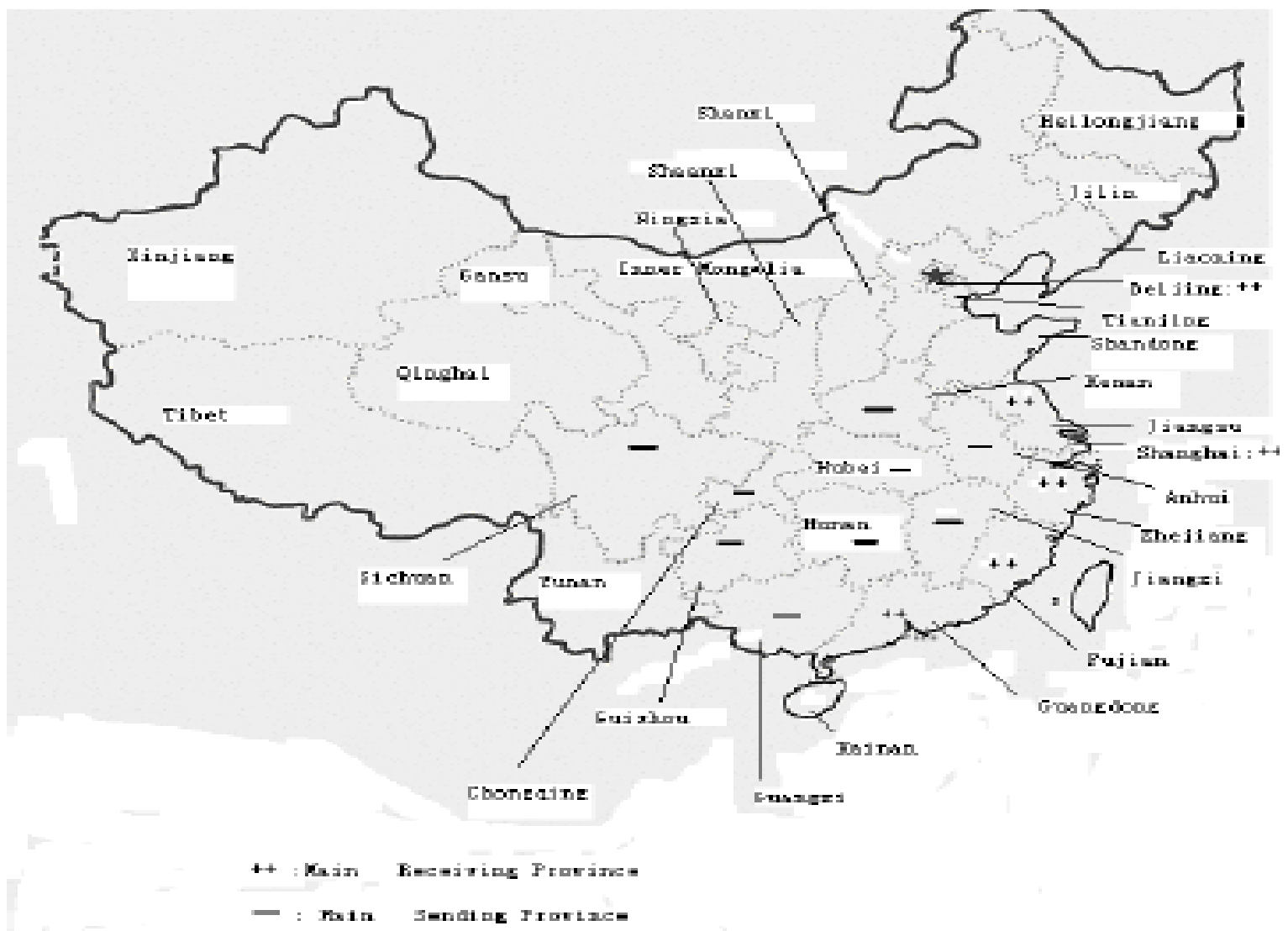

Figure 6. Mapping the rural labour migration: Origins and destinations in China. (Souce: Huang \& Pieke, 2003)

State investment was pumped into the eastern region, along with preferential policies that made that region attractive to foreign investment. It affects the development gap between the eastern region and the rest of China has widened over time. In 1985, the GDP per capita for the eastern region was 1.45 times than that of the center region and 1.07 that of the western region; these ratios increased into 1.94 and 2.47 in 2003, respectively.

\section{Migrant Labors and Rural Development in China}

Rural areas in China have been long neglected by the state in exchange of the economic development and transformation of the urban areas. This led to the deterioration of the condition and welfare of the Chinese in the rural areas and villages. Agricultural works as a means for their survival were not enough to sustain them 
and provide them with their basic needs and requirements that are necessary for their survival in their everyday living.

These neglect and apathy from the state also hamper the job opportunities in the rural areas. The state has overlooked most of the rural areas in providing for policies that are vital for the expansion of agricultural and non-agricultural jobs that are needed in that area.

With the increasing development of the urban areas, migration has been seen by the rural Chinese to be the immediate solution to their rural problems. They took any jobs in the urban areas, just to survive. Most migrant laborers are employed in jobs which are generally considered "dirty, dangerous, and difficult" and which the urban inhabitants are unwilling to take. Today, migrant laborers in China significantly contribute to the development of industries, such as construction, commerce, food services, and sanitation. They play a chief role in the general improvement of life in the urban centers.

\section{Migrant Labors’ Contributions to Rural Development}

Much has been said for the role that the migrant labors did for the development of the urban areas, they were one of the main agents of its transformation and economic development, and up to this date they are still the ones who mainly provide most of the labor requirements that these economic centers need. However, there is just little that we heard or read on what and how the migrant labors are contributing for rural development, or if they are really contributing something on the development of the rural areas.

That is the aim of this part of the paper, to cast some light and give an analysis on how migrant labors are contributing not only for the development of the urban areas but as well as the rural areas. We will look on their overall contributions as well as its positive impact on rural transformation and development.

\section{From Agricultural to Non-agricultural Work}

Migrant labors' income from their migratory work has a bigger difference compared to their income from agricultural work. Moreover, the share of non-agricultural work in the total rural income has grown and increased enormously.

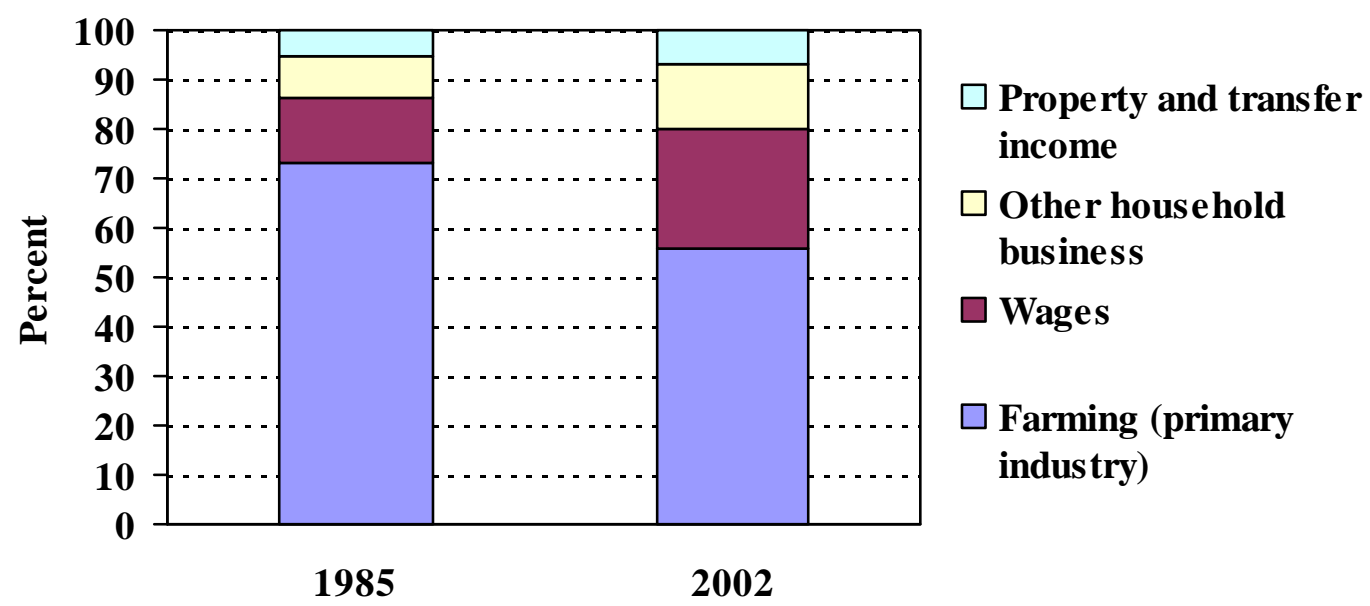

Figure 7. Declining share of farm activities in rural household income. (Source: National Bureau of Statistics, Rural Household Survey, 2000)

According to Zhang (2000), since the 1990s, more than 90\% of rural household income has increased which mainly came from non-agricultural activities (Zhang, Lohmar, \& Gale, 2004). Most of the rural Chinese 
turn into non-agricultural work, which gave them much additional salary that is increasing every year compared from what they can get from agricultural work.

Table 1

Per Capita Income for Rural Households

\begin{tabular}{lllll}
\hline Total net income & 1985 & 1995 & 2000 & 2001 \\
\hline Wage income & 72.15 & 353.7 & 702.3 & 771.9
\end{tabular}

Notes. Source: China Statistical Yearbook, 2002; this is a modified version of Table No. 1 (Per Capita Income of Rural Households) lifted from Huang and Pieke (2003).

\section{Remittances}

One of the main objectives of migrant labors for their migration to urban areas is to have a job that will give them more salary that can send back to their home areas, which in turn they will use it upon their return and for their family's consumption. It is one of the main integral points of why they leave their home villages.

Looking at today's internal migration scenario, the young rural migrants do contribute to raising the standard of living in the countryside. They usually send remittances back on a monthly or quarterly basis and bring their saving back home yearly. Remittances are mostly used to meet daily expenses and have clearly contributed to the survival of many poor families and local communities (Zhang et al., 2004, p. 14). Moreover, remittances sent via post offices are likely to represent only half of the total sent home by migrants with the rest usually brought back at Chinese New Year or the autumn harvest (Ping et al., 1997; Zhao, 2003) ${ }^{4}$.

Mostly, labor migrants send a huge amount of remittances back, although most of these are used for household consumption and daily expenditure, including building and decorating new houses, wedding, and funeral ceremonies (Center for Rural Economy Studies, 1996).

For local governments who are sending migrants to urban areas, they looked into migration as vital sources of investment, entrepreneurship, and experience on their return. Research on returned migrants has shown that they contribute positively to the economy of the home area (Sheng, 2007).

In the study conducted by a consultative group, 400 migrant workers were surveyed on how and in what way they send their remittances to their families back in the villages, the research showed that they utilized the services of China post, commercial banks, and cooperatives in relation to their remittances (Cheng \& Zhong, $2005)^{5}$. The percentage breakdown of formal routes for sending remittances is as follows:

\footnotetext{
${ }^{4}$ Cited on a 2007 World Bank report on Migration in China.

${ }^{5}$ Cited in Rachel Murphy (2006). “Domestic Migrant Remittances in China: Distribution, Channels and Livelihood”, A paper report for International Organization for Migration, p. 11.
} 


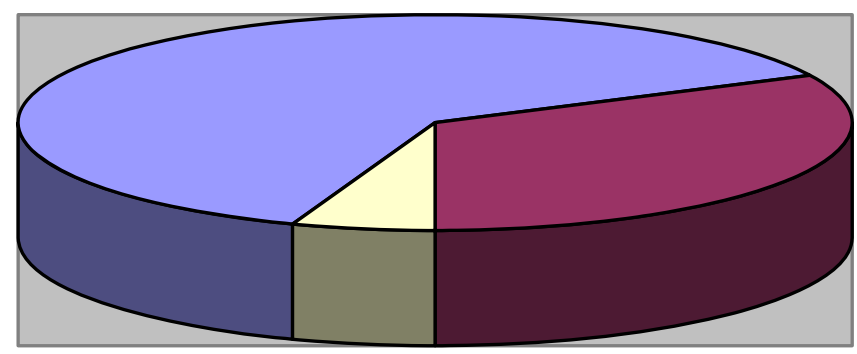

\begin{tabular}{|l|}
$\square$ Post Office \\
$\square$ Commercial Banks \\
$\square$ Rural Cooperatives \\
\hline
\end{tabular}

Figure 8. Percentage of formal routes of rural migrant's remittances.

(Percentage: (Post Office (62\%), Commercial Banks (32\%) and rural cooperatives (5.5\%)). ${ }^{6}$

Moreover, from this chart we can see how China post is able to dominate the remittance services market because it has an expansive computerized network covering many rural communities. On the one hand, informal remittance channels usually carry the money on their return to the village ${ }^{7}$.

Moreover, remittances sent via post offices are likely to represent only half of the total sent home by migrants, with the rest usually brought back at Chinese New Year or the autumn harvest (Ping et al., 1997; also Zhao, 2003) ${ }^{8}$.

\section{Investments}

Investments by migrant labors in China can be classified into two: productive and consumptive investments. They either invest their money to other things that can generate more money for them or they use it for their own welfare and consumption, or sometimes they usually invest on both kinds.

We can say that investments are the by-products of the remittances of migrant labors; this is where their money goes. Investments are very important for the development of the rural areas; it serves as a vehicle that the rural areas can use in order to provide opportunity for other rural Chinese who cannot migrate or for those who stay in the villages or home areas.

Productive investment. Remittances that are used in this kind of investment are important and crucial in the development of rural areas because some of the money and resources from the remittances of the migrant labors are being poured into agriculture, land, and business creation.

Agriculture. Not all people in rural China migrate into urban areas, much of the population in the rural areas stays, and much of them are still tied in agriculture. Normally, only one member of the family is encouraged to migrate for off-farm work (Huang \& Pieke, 2003, p. 12).

Most remittances used for agricultural purposes were directed towards purchasing additional inputs to substitute for the labor lost through migration of a household member (Murphy2002, p. 23). Since migration of one or more family members into urban areas, it will affect the manpower requirements for agriculture. Thus, their families also invest on agricultural equipments and machines, items of investment including threshers, water pumps, plowing machines, seeders, grain processors, and feed processors (Zhao, 1999).

\footnotetext{
${ }^{6}$ Ibid., p. 11.

7 Ibid., p. 12.

${ }^{8}$ Cited in Ping Huang and Frank Pieke (2003). “China Migration Country Study” (p. 14).
} 
With the increase in resources that they can use, farmers are now also investing to high quality seeds, adopting farming technologies which can help to cut labor input and the use of chemical fertilizer and pesticide to increase output (Sheng, 2007).

Land. Because of the increasing number of rural people migrating to urban areas, land in the rural areas being left alone, they give the responsibility to other people to till and manage their lands. Having this kind of scenario, some rural migrants see an opportunity on it for possible investments.

Remittances provide a way for rural people to obtain a desirable property location and by extension, to gain access to local credit (Murphy, 2002, p. 26). They used their newly-managed land as a means to acquire loan for additional money that they can use for other investments.

Business creation. Having exposed to entrepreneurial culture and capitalist spirit in the urban and coastal areas, some returned migrants used their urban savings as well as their urban contacts, skills, and information to set up businesses in their home areas.

Most of factories they established are labor-intensive branches or processing for companies which they previously worked in the coastal regions (Ma, 1999). They see this as an opportunity to have a business, since doing a business in the rural areas is a lot cheaper compared to the business cost in the urban areas.

At the same time, outsourcing has been a new trend today in business, and most of the products and goods of most of the companies are produced and manufactured by other companies to save and cut cost. This has been done by rural migrants upon their return to their rural villages; they encouraged their former employers to outsource to them their products or other-related goods on their products.

In this way, we can see how they used their money to acquire more money, which in turn they are able to help their fellow villagers to have a work in non-agricultural activity situated in their home areas.

Consumptive investment. Another area where most migrant labors invest is for their own well-being and comfort. They use their money or their families are using their remittances in order to survive and to be able to buy some luxuries in life. Most of the investments in this kind are focused on the following: consumer goods, house building, and health and education.

Consumer goods. In everyday life, remittances help to pay for everyday items, such as soap, matches, batteries, and clothes. As poverty is rampant in rural areas, paying for basic needs is one of the most important things that rural migrants' remittances went to.

In middling and richer regions, remittances have sustained rural consumption of manufactured goods. Demands for goods, such as television sets, air conditioning units, washing machines, and motorcycles, have been particularly strong, and the rural demand for these items increased by $17 \%$ in 2003 (Kynge, 2003) ${ }^{9}$.

Furthermore, remittances are commonly used by rural people to buy the consumer goods as part of the gifts exchanged at lifecycle celebrations, in particular marriages (Murphy, 2002, p. 29). Rural Chinese used their remittances in order to pay for the dowry which is a vital part of marriage in the rural areas.

House-building. One important thing for the rural Chinese is to have a decent house which they can be proud of, thus the lion's share of remittances and urban savings are used for house repairs and house construction. A report in Renmin Ribao (2006, Feb. 6), in Yudu county in Jiangxi province finds that rural households allocate roughly $60 \%$ of their remittances to house construction.

\footnotetext{
${ }^{9}$ Cited on a World Bank Report on Migration in China (2000).
} 
Another important aspect of marriage in rural China besides dowry is to have a house that you can present to your wife to be. Thus, in Chinese society, it is nearly impossible for a man to find a bride if he does not have a respectable house to offer her (Murphy, 2006, p. 29).

Moreover, a smaller portion of rural people use their urban savings to buy a house in the county seat (Sheng, 2007, p. 5). This is a way for them to establish an urban lifestyle closer to home. It is also a way for them to ensure their children are able to attend better quality primary, middle, and high school education.

Health and Education. Another common uses of remittances in rural areas are expenditure on health and education. In most rural China, medical care is largely privatized and involves the payment of user fees. In addition to that, residents in those areas also lacked the money to pay for teachers' wages as well as to buy school materials for their children (Sheng, 2007, p. 29).

\section{Human Capital}

More than the monetary aspect of migration which migrant labors are using back to their home areas, another important contribution that they added in achieving rural development is the transfer of knowledge and skills that they acquired in the urban areas.

This aspect of migrant labors' contribution to rural development has been echoed to the author by one of distinguished and noticeable foreign journalist in China, CNN (Cable News Network) Bureau Chief Jaime Florcruz $^{10}$. He explained that the rural migrants acquired new knowledge and technique which they can share to their rural areas as they returned from their work and exposure from urban areas.

Furthermore, through migration, rural laborers have expanded their experiences, improved the quality of their work, and further enhanced their skills (Ma, 1999; Murphy, 2002; World Bank, 2007). The reason for this was because of their exposure on how it is to work on a non-agricultural work, which involved not only of pure manpower skills but also of management and technical skills can be an important factor for their working experienced.

Experienced migrant workers with a relatively long migration duration of 5-10 years will already learn some technical and management skills as well as market competition and risk management, which are used in their return to their home areas as a boss (lao ban) rather than as a migrant worker (da gong zhei or da gong mei) (Ma, 1999).

Moreover, some migrant laborers have become leaders in their communities after their return to their home villages primarily because of their newly acquired knowledge and skills from the urban areas. Through these newly acquired skills and urban experiences they became very suitable to become village leaders in their own community. In addition to that, their fellow village mates are hoping that they can induce something on their society which may lead to their development and their society's transformation.

\section{Analysis}

Migration of rural Chinese in the urban areas gave some slight changes on their living conditions and status in the rural areas. We can see that because of their migratory work, it improved in filling the poverty gap between urban and rural areas. Although, we cannot say that migration will be the answer to close the gap or narrowing it totally. Through the years, it became one of the important elements in achieving development in

\footnotetext{
10 The author interviewed Mr. Florcruz during the sidelines of the "Philippine-China Friendly Dialogues: In Search for Greater Maturity” last 27 September 2008 at Richmonde Hotel, Pasig City, Philippines.
} 
the rural areas. However, there is a lot of catching-up to do in order for the rural areas to be at the same place and position with the urban areas.

The rural Chinese has seen non-agricultural work and internal migration as vehicles and instruments of opportunities. Arable land in China is depleting and that surplus labor in agriculture is so high that many people have been displaced and cannot anymore work in the farm areas. Jobs in the urban areas and in non-agricultural work sector have been the answer to accommodate the surplus laborers in agriculture. However, the problem lies on the lack of knowledge and technical skills of these surplus laborers in order to match them with the existing jobs available.

Remittances of migrant labors play a lot of difference in the development of rural areas. It fuels the development of rural economy through the usage of money by the migrants' family and at the same time, the money that these migrants are pouring back to their home areas is vital in the absence of resources and money that the government usually spends on these areas.

Labor migrants have been playing a vital role not only in helping the development of the rural areas but also the development of its populace who just stay in the villages and cannot migrate. They become agent of catalyst themselves as they invest and employ the techniques that they learned from the urban areas and through their works in the non-agricultural sector.

\section{Conclusion}

The future of labor migrants in China is bright and hopeful. The positive impact that they contribute for rural development will continue and it will further increase if proper policies are implemented by the state, ensuring their welfare and development in the urban areas. Support and policies from the central government are needed in to order to protect the rural migrants.

The central government must shift its policy of development that will prioritize both urban and rural areas. The "go-west" policy of the state must also continue and it must be properly implemented in the rural areas. Giving the much needed attention and support that these areas need, state investments and revenue must pump in the areas so as to spur development and investments both from local businessmen and foreign companies.

Internal migration can be one of the solutions to the problems of rural areas, particularly its issue of development. However, the state must never solely rely on it; they must do something in order to help the people from the rural areas. After all, migratory work is just an immediate choice of the rural Chinese to their problems, and still the answer lies on the hands of the state.

\section{References}

Cai, F. (1999). Spatial patterns of migration under China’s reform period. Asian and Pacific Migration Journal, 8(3), 313-327.

Huang, P., \& Pieke, F. (2003). China migration country study. Proceedings from The Regional Conference on Migration, Development and Pro-Poor Policy Choices in Asia, Dhaka, Bangladesh.

Li, C. (2007). Citizenship, equality and reformation of household registration system in China from the perspective of international human rights perspective. Retrieved from http://www.uio.no/studier/emner/jus/humanrights/HUMR5190/h07/undervisningsmateriale/Cheng_Li_Presentation.doc

Ma, Z. D. (1999). Social capital mobilization and income returns to entrepreneurship: The case of return migration in rural China. Environment and Planning, 34(10), 1763-1784.

Murphy, R. (2002). How migrant labor is changing rural China. Cambridge: Cambridge University Press.

Murphy, R. (2002). Migrant labor is changing rural China. Cambridge: Cambridge University Press. 
Murphy, R. (2006). Domestic migrant remittances in China: Distribution, channels and livelihoods. Geneva: International Organization for Migration.

Sheng, L. Y. (2007). Rural labor force emigration on the impact and effect of macro-economy in China. Retrieved from http://www.stats.gov.cn/english/icas/papers/P020071114297555473181.pdf

Zhang, L. X., Lohmar, B., \& Gale, F. (2004). New opportunities for economic analysis with rural household data in China. Retrieved from https://scholar.harvard.edu/bauhoff/chinadata.html

Zhao, Y. H. (1999). Labor migration and earnings differences: The case of rural China. Economic Development and Cultural Change, 47(4), 767-782. 